\title{
A Critique of Immunity for Multilateral Development Banks in National Courts
}

\author{
Chengjin $X u$ \\ Assistant Researcher, Center for International Economic and Technological \\ Cooperation, Ministry of Industry and Information Technology of the People's \\ Republic of China, Beijing, P.R. China \\ xucj@cietc.org \\ Bin $G u$ \\ Assistant Professor, Law School of Beijing Foreign Studies University (B FSU), \\ Beijing, P.R. China \\ gubin@bfsu.edu.cn
}

\begin{abstract}
Since their emergence after World War II, multilateral development banks (MDBs, or Banks) have become crucial players in promoting economic development in the developing world. The theory of immunity enables the MDBs to shield themselves from jurisdictions of national courts, and protects them in Bank operations. This paper presents a critique of the immunity claimed by MDBs, and argues that such a claim of immunity should be restrictive, rather than absolute. Meanwhile, it is important to establish adequate dispute settlement systems within the MDBs, counterbalancing their immunities from legal process. The systems offer a fair trial to private parties, and should be independent from Bank management. As for the Asian Infrastructure Investment Bank (АІІB), the young Bank's operations can be on the ground only with its immunities respected by members, while the committed high standards are possible only with adequate internal dispute settlement systems.
\end{abstract}

\section{Keywords}

multilateral development banks - AIIB - immunity - functional necessity - dispute settlement 
Since their emergence after World War II, multilateral development banks (MDBs) have become crucial players in promoting economic development in the developing world. As their involvement in economic activities grows deeper, disputes on the banks' actions arise inevitably. The theory of immunity enables the MDBs to shield themselves from jurisdictions of national courts, and protects them in Bank operations.

This paper presents a critique of the immunity claimed by MDBs, and argues that such a claim of immunity should be restrictive, rather than absolute, in national courts. Meanwhile, it is important to establish adequate dispute settlement systems within the MDBs, counterbalancing their immunities from legal process. Such systems offer a fair trial to private parties, and should be independent from Bank management.

The Asian Infrastructure Investment Bank (АІІв) is the first MDв initiated by China alongside a group of Asian developing countries, and has drawn the world's attention. The young Bank is conceived for the 21st century, ${ }^{1}$ and commits to a modus operandi-lean, clean and green. ${ }^{2}$ Its operations are only possible with its immunities respected by its member states, while its high standards can only be on the ground with fair and effective dispute settlement systems. We will look into the АІІв throughout this study.

Section 2 of this paper provides an overview of MDBs, and the purpose of their creation and practices. Section 3 examines the theory of immunity in international law, and the doctrine of functional necessity that enables an international organization to enjoy immunity. Section 4 discusses the application of the theory of immunity on MDBs. The discussion is conducted from three perspectives: international treaty, national law and judicial forum. Section 5 describes two examples of internal dispute settlement systems as counterbalance of MDв immunities. Section 6 concludes.

\section{$2 \quad$ Multilateral Development Banks: An Overview}

Multilateral development banks are international organizations, with special purpose of fostering economic and social development in the world or in a

1 http://www.aiib.org/html/aboutus/introduction/aiib/?show=o (visited December 28, 2016).

2 The modus operandi is defined as follows: lean, with a small efficient management team and highly skilled staff; clean, an ethical organization with zero tolerance for corruption; and green, an institution built on respect for the environment. http://www.aiib.org/html/ aboutus/introduction/aiib/?show=o (visited December 22, 2016). 
particular region. ${ }^{3}$ As international organizations, MD Bs have legal personality independent from their member states. "Having international legal personality for an international organization means possessing rights, duties, powers and liabilities etc. as distinct from its members or its creators on the international plane and in international law." ${ }^{3}$ Based on this definition of international legal personality, an intrinsic feature of MDBs is that they must be able to be held accountable for their own actions, and this feature must be observed and given effect in practice. In this section, we will recall the creation of MDBs, their mission and purpose, as well as their legal status under international law.

\subsection{What are Multilateral Development Banks and What are They Doing}

The oldest MD B is the World Bank (or International Bank for Reconstruction and Development, IBRD), which was established in 1944, serving as one of the three pillars of the Bretton Woods system created after the World War II and as a special agency of the United Nations. ${ }^{5}$ All other MDBs are limited to a particular region. These regional MDBs include the Inter-American Development Bank (IDB), the African Development Bank (AfDB), the Asian Development Bank (ADB), the European Bank for Reconstruction and Development (EBRD), and the young AIIB and New Development Bank. ${ }^{6}$

MDBs provide financial assistance and professional advice for economic and social development in developing countries. ${ }^{7}$ The financial supports are supplied in form of loans and grants. ${ }^{8}$ For long-term loans, the MDBs borrow the funding on the international capital market and re-lend the funding

3 The World Bank, http://web.worldbank.org/WBSITE/EXTERNAL/EXTABOUTUS/o,,content MDK:20040614 menuPK:41699 pagePK:43912 piPK:44037 theSitePK:29708,oo.html; Leonardo A. Crippa, Multilateral Development Banks and Human Rights Responsibility, 25 AM. U. INT'L L. REV. 531, 533 (2010).

4 Nigel White, the law of International Organizations 30 (quoting Amerasinghe, Principles of the Institutional Law of International Organizations 78) (2nd ed. 2005).

5 Rebecca M. Nelson, Multilateral Development Banks: Overview and Issues for Congress, at 2 (April 9, 2010), available at www.fas.org/sgp/crs/row/R41170.pdf.

6 New Development Bank is a multilateral development bank newly established by the five BRICS countries, i.e., Brazil, Russia, India, China and South Africa in July 2015, half a year earlier than the establishment of the AIIв. The BRICs' New Development Bank plans to expand membership starting 2017 .

7 The World Bank, 'Multilateral Development Bank', http://web.worldbank.org/WBSITE/ EXTERNAL/EXTABOUTUS/o,,contentMDK:20040614 menuPK:41699 pagePK:43912 piPK: 44037 theSitePK:29708,oo.html.

8 Nelson, MDBs: Overview and Issues for Congress, at 2. 
to developing countries at a market-based interest rate. ${ }^{9}$ The member states of MDBs will donate funding to the MDBs, which in turn lend to developing countries in need, in form of very-long-term loans at below market interest rate. ${ }^{10}$ Some MDBs also offer grant financing, mostly for technical assistance, advisory services, or project preparation. ${ }^{11}$ In general, the mission and purpose of the MDBS is to increase living standard for people in developing countries by funding a development project in a particular region. For example, the AIIB stipulates its purpose in its Articles of Agreement (AOA):12

The purpose of the Bank shall be to: (i) foster sustainable economic development, create wealth and improve infrastructure connectivity in Asia by investing in infrastructure and other productive sectors; and (ii) promote regional cooperation and partnership in addressing development challenges by working in close collaboration with other multilateral and bilateral development institutions.

The purpose of the MDBs should be observed in evaluating MDBs' actions and the legal institutions applied to the MDBs. Any practice that in effect hampers the realization of the purpose shall be subject to change.

\subsection{Multilateral Development Banks as International Organization}

To be an international organization, an entity must be created by a multilateral treaty, consist of sovereign states, and possess institutional organ of its own. ${ }^{13}$ MDBs meet all these standards. MDBs arise out of state-created constituent instruments, which are often referred to as Articles of Agreements. ${ }^{14}$ The Articles of Agreements not only establish the MDBs, but also set forth all fundamental

9 World Bank, 'Multilateral Development Bank', http://web.worldbank.org/WBSITE/ EXTERNAL/EXTABOUTUS/o,,contentMDK:20040614 menuPK:41699 pagePK:43912 pi PK:44037 theSitePK:29708,0o.html.

$10 \quad I d$.

11 Id. During AIIB first annual meeting June 2016, China contributed \$50 million to establish a Project Preparation Special Fund at AI B. The Special Fund is expected to provide grants to the Bank's low and middle-income member countries for preparation activities, including environmental, social, legal, procurement and technical assessments and analyses, and advisory services. AIIB, "AIIB's Board of Directors establish a Project Preparation Special Fund China provides initial \$50 million start-up contribution," http://www.aiib .org/html/2016/NEWS_0625/123.html (visited January 14, 2017).

12 AIIB AOA Art. 1.1.

13 Nigel White, at 1.

14 Crippa, $M D B$ and Human Rights Responsibility, at 533-34. 
principles and regulations of the MDBs, including the purpose of the bank, membership, structural framework, capital arrangement, as well as the bank's legal responsibility and immunity. ${ }^{15}$

MDBs are comprised of and governed by their members, most of which are sovereign states. For example, as a subordinate of the United Nations, all the members of the World Bank are sovereign states. ${ }^{16}$ Some MDBs, however, involve non-state members. For example, Hong Kong, China is a member of the АDB. ${ }^{17}$ The АIIв, by making reference to ADB membership, ${ }^{18}$ accepts non-state members as well.

The Board of Governors, Board of Directors and management are the most important institutional organs of MDBs. The Board of Governors is composed of representatives from all member states and is vested with the ultimate power to make policies for the MDв. ${ }^{19}$ The power to oversee a bank's business and daily functions is delegated to the Board of Directors, which comprises certain number of executive directors who work full time at the headquarters of the bank. ${ }^{20}$ But the AIIB has a unique, non-resident Board, ${ }^{21}$ meeting only four times a year. ${ }^{22}$ АІІв management is thus expected to be more accountable

15 Articles of Agreement of the IBRD, available at http://web.worldbank.org/WBSITE/ EXTERNAL/EXTABOUTUS/o,,contentMDK:20049557 menuPK:6300o6o1 pagePK:34542 piPK:366oo theSitePK:29708,oo.html; Agreement Establishing the Asian Development Bank, available at http://www.adb.org/documents/reports/charter/default.asp; Agreement Establishing African Development Bank, available at http://www.afdb.org/ fileadmin/uploads/afdb/Documents/Legal-Documents/30718627-EN-AGREEMENT -ESTABLISHING-THE-AFRICAN-DEVELOPMENT-BANK-6TH-EDITION.PDF; Agreement Establishing Inter-American Development Bank, available at http://www.oas.org/dil/ treaties_C-15_Agreement_Establishing_the_Inter-American_Development_Bank.htm; Agreement Establishing European Bank of Reconstruction and Development, available at http://ec.europa.eu/world/agreements/downloadFile.do?fullText=yes\&treatyTransId=1357 .

16 The World Bank, World Bank Group Members, http://web.worldbank.org/WBSITE/ EXTERNAL/EXTABOUTUS/ORGANIZATION/BODEXT/o,,contentMDK:20122871 page PK:64020054 piPK:64020408 theSitePK:278036 isCURL:Y,oo.html.

17 Asian Development Bank, 'Membership', http://www.adb.org/about/membership.asp.

18 AІІв AOA Art. 3.1 provides that "Membership in the Bank shall be open to members of the International Bank for Reconstruction and Development or the Asian Development Bank".

19 The World Bank, 'Organization', http://www.worldbank.org/en/about/leadership.

20 Id.

21 AIIB AOA Art. 27.1.

22 АІв By-Laws Section 2(b) provides that "Said Rules of Procedure shall provide, inter alia, for regular meetings of the Board of Directors at least quarterly, for special and electronic meetings, and for voting without meeting, as provided in Article 27 of the Articles 
for daily decision-making than its counterparts in other banks. Usually, MDB members do not share equal decision power on the bank's business as in international political organizations, such as the United Nations. A member's voting power at the bank is decided by that member's financial contribution to the bank's capital stock. ${ }^{23}$

\subsection{MDBs' International Legal Personality}

International legal personality is not necessary in order to found an international organization, ${ }^{24}$ but a great majority of international organizations do possess international legal personality, which allow an organization to enjoy rights, undertake obligations, and assume responsibilities. MDBs are international organizations that have legal personality and are subject to public international law. ${ }^{25}$

First and foremost, the MDBs declare in their Articles of Agreement that they have international legal personality. For example, the Article 45 of the AIIB's Article of Agreement provides: "The Bank shall possess full juridical personality, and in particular, the capacity: (i) to contract; (ii) to acquire and dispose of immovable and movable property; (iii) to institute and respond to legal proceedings; and (iv) to take such other action as may be necessary or useful for its purpose and activities." Almost identical provisions exist in the constituent instruments of the IBRD, ${ }^{26} \mathrm{ADB},{ }^{27}$ EвRD, ${ }^{28}$ and IDв. ${ }^{29}$ The AfDB's Articles of Agreement sets forth the bank's legal status more generally: "To enable it to

of Agreement." In correspondence, AII B Rules of Procedure of the Board of Directors Section 3 (b) provides that "Pursuant to Section 2 (b) of the By-Laws, the Board shall hold regular meetings at least quarterly in each year. The Board may be called into session at any time by the President on his own initiative. The President shall call the Board at any time at the written request of any three (3) Directors."

23 Crippa, $M D B$ and Human Rights Responsibility, at 535.

24 Nigel White, at $1-2$.

25 Id. at 30.

26 Articles of Agreement of IBRD, art. VII § 2, available at http://web.worldbank.org/ WBSITE/EXTERNAL/EXTABOUTUS/o,,contentMDK:20049696 pagePK:43912 piPK:36 $602,00 . h t_{m l} \#$ I3.

27 Agreement Establishing the Asian Development Bank, art. 49, available at http://www .adb.org/documents/reports/charter/charter.pdf\#page=26.

28 Agreement Establishing the European Bank of Reconstruction and Development, art. 45, available at http://ec.europa.eu/world/agreements/downloadFile.do?fullText=yes\&treat yTransId $=1357$.

29 Agreement Establishing the Inter-American Development Bank, art. XI § 2, available at http://www.oas.org/dil/treaties_C-15_Agreement_Establishing_the_Inter-American Development_Bank.htm. 
fulfill its purpose and the functions with which it is entrusted, the Bank shall possess full international personality."30

The MDBs' independent legal personality is also reflected in the fact that the banks have separate will from their member states. "Separate 'will' is a major, perhaps defining, element of international legal personality."31 The depth of membership, the nature of decision making, and the presence of majority voting in the organs are factors that will be considered in finding separate will. ${ }^{32}$ Take the AIIв for example. It has 57 founding member states, representing a wide range of international community; ${ }^{33}$ it is difficult for a couple of states to seize control of the bank and to deprive the bank of its own will. The bank implements multilateralism. The power to make regular business decisions and important policy decisions are vested in management, the Board of Directors, and the Board of Governors, respectively. ${ }^{34}$ Their decisions reflect the will of the bank. With respect to the voting mechanism, although the voting power at an MDв depends on a member state's financial contribution to the bank, which gives economically stronger countries more voice in the bank, the bank's Articles of Agreement clearly states that "all matters before the Bank shall be decided by a majority of the votes cast." ${ }^{35}$ Accordingly, the MDBs possess separate will and international legal personality.

Furthermore, the MDBs are subject of international law. Under international law, the MDBs have treat-making capacity, possess capacity to bring claims, and enjoy privileges and immunities. ${ }^{36}$ First, MDBs enter into agreements with peer organizations. For example, the АІІв works "in close collaboration with other multilateral and bilateral development institutions", ${ }^{37}$ as

30 Agreement Establishing the African Development Bank, art. 50, available at http:// www.afdb.org/fileadmin/uploads/afdb/Documents/Legal-Documents/30718627-EN -AGREEMENT-ESTABLISHING-THE-AFRICAN-DEVELOPMENT-BANK-6TH-EDITION.PDF. Nigel White, at 1.

$32 \quad I d$. at 31.

33 AIIB founding members include BRICS and other emerging countries, developing countries, least developed countries, and Western developed countries. See AIIв membership at http://euweb.aiib.org/html/aboutus/governance/Membership/?show=1 (visited January 15, 2017).

34 The World Bank, 'Organization', http://www.worldbank.org/en/about/leadership.

35 IBRD Articles of Agreement, art. v § 3, available at http://web.worldbank.org/WBSITE/ EXTERNAL/EXTABOUTUS/o,,contentMDK:20049604 pagePK:43912 piPK:36602,0o.html\#I4.

36 Nigel White, at 34.

37 AIIB AOA Art. 1.1. 
demonstrated at both MOU (i.e., Memoranda of Understanding) ${ }^{38}$ and project levels. ${ }^{39}$ Second, with respect to the capacity to bring claims, the International Court of Justice has opined that international organizations have the capacity to bring claims against a state for damages caused by the state's breach of obligation towards the organization. ${ }^{40} \mathrm{MDBs}$ are international organizations and thus have the capacity to bring claims before a judicial tribunal. Third, MDBs enjoy a broad range of privileges and immunities - mostly as broad as foreign sovereigns - from national jurisdictions. The privileges and immunities for MDBs, as international organizations, are recognized and provided in their own constituent instruments ${ }^{41}$ and in national legislation. ${ }^{42}$

\section{3 \\ Immunity Theory in International Law}

This Section will recall the theory of immunity in international law, and discuss the rationale behind immunity for international organizations.

\subsection{Immunity Theory under Public International Law}

The immunity doctrine derives from the recognition of the "perfect equality and absolute independence of sovereigns." ${ }^{43}$ A sovereign and its representatives are absolute within its own territory and are exempt from arrest and detention within a foreign territory. ${ }^{44} \mathrm{At}$ its origin, the concern of the immunity theory is to protect a sovereign from the jurisdiction of the territorial courts. ${ }^{45}$

38 The AIIB has signed non-binding Memoranda of Understanding with the ADB, the EBRD and the European Investment Bank. http://euweb.aiib.org/html/aboutus/introduction/ Cooperation/?show $=0$ (visited January 14, 2017).

39 The АІІв has signed co-financing agreements with the ADв, the EвRD, the World Bank and other financial institutions. http://euweb.aiib.org/html/2016/PROJECTS_1010/163 .html (visited January 15, 2017).

40 Reparation for Injuries Suffered in the Service of the United Nations, Advisory Opinion, 1949 I.C.J. 174, 179.

41 IBRD Articles of Agreement, art. VII § 3; Agreement Establishing Asian Development Bank, art. 50; Agreement Establishing African Development Bank, art. 52; Agreement Establishing European Bank for Reconstruction and Development, art. 46.

42 United States International Organizations Immunities Act, 22 U.s.C. $§ 288$ (1945).

43 Ian Brownlie, Principles of Public International Law 322 (6th ed. 2003) (quoting Schooner Exchange v. McFaddon, 7 Cranch 116 (1812)).

$44 \quad I d$.

45 Id. 
The rationale of the immunity doctrine rests on "the dignity of the foreign nation, its organs and representatives, and on the functional need to leave them unencumbered in the pursuit of their mission." In theory, the necessity of freedom for a sovereign to properly perform its function is a precondition to grant immunity.

As sovereign states' involvements in commercial activities grew to a considerable scale at the end of the nineteenth century, the immunity doctrine evolved a distinction between acts of government, jure imperii, and acts of commercial nature, jure gestionis. ${ }^{46}$ In the latter case, a sovereign state's request for immunity from national jurisdiction is denied. ${ }^{47}$ This so-called restrictive immunity approach gradually received wide recognition in the twentieth century. Many countries have codified the restrictive doctrine of immunity into their national legislations. ${ }^{48}$ Take the United States Foreign Sovereign Immunities Act of 1976 for example: sovereign states generally enjoy immunities, except in cases

in which the action is based upon a commercial activity carried on in the United States by the foreign state; or upon an act performed in the United States in connection with a commercial activity of the foreign state elsewhere; or upon an act outside the territory of the United States in connection with a commercial activity of the foreign state elsewhere and that act causes a direct effect in the United States. ${ }^{49}$

In addition to the commercial activity exception, claims against sovereign states for "personal injury or death, or damage to or loss of property ... caused by the tortious act or omission" of that sovereign state also deprives the state of its recourse to immunity. Although it is inaccurate to assert that there has been a consensus that absolute immunity has been replaced by restrictive immunity, a trend toward accepting the restrictive doctrine of immunity had been embodied in states' legislative practices since 1970 s. $^{50}$

$46 \quad$ Id. at 323 .

$47 \quad I d$.

$48 \quad I d$. at 324.

4928 U.S.C. $§ 1605(\mathrm{a})(2)$.

5o See Brownlie at $325^{-26}$. The restrictive doctrine of immunity is represented in the European Convention of 1972, the United Kingdom State Immunity Act of 1978, the Australian Foreign States immunities Act of 1985, and the Canadian State Immunity Act of 1982 . 
The Rationale Behind International Organizations' Immunities: Functional Necessity

An international organization itself does not enjoy sovereignty; it is an organization established by international agreement between sovereign states and whose membership consists entirely or principally of states. ${ }^{51}$ Therefore, the immunity for international organizations cannot stem from the idea of absoluteness and supremacy of sovereignty. The rationale for international organization's immunity is based on the concept of functional necessity, which means that "an entity shall be entitled to (no more than) what is strictly necessary for the exercise of its functions in the fulfillment of its purposes." ${ }^{2}$ At core of the concept of functional necessity, the term "function" denotes the tasks of an organization or activities carried out by the organization as a tool for accomplishment of its purposes. ${ }^{53}$ Function possesses an inherent quality and implication of obligations, pursuant to which the international organization must perform in order to pursue the goals that its member states have in common and refrain from taking activities which may hamper the accomplishment of such goals. ${ }^{54}$ Both the positive and negative obligations define the scope of functional immunities that an international organization may be entitled to.

A number of reasons justify granting privileges and immunities to international organizations based on functional necessity. An international organization cannot truly act for the common interests of all member states, unless it can act independently from control or influence of any individual state. One of the most effective and threatening means of control is to subject the organization's act to a state's national jurisdiction. ${ }^{55}$ In order to fulfill its international tasks, it is necessary to grant the organization a certain degree of political independence, which constitutes the primary reason for according privileges and immunities to the organization. ${ }^{56}$ Furthermore, an organization cannot act in a convincing manner towards its member states unless the member states have confidence in that the organization will treat them on an equal basis. ${ }^{57}$

51 Peter H.F. Bekker, The Legal Position of International Organizations: A Functional Necessity Analysis of Their Legal Status and Immunities 39 (1994).

$52 \quad I d$.

53 Id. at 45 .

54 Id. at $49-50$.

$55 \quad$ Id. at 100.

$56 \quad I d$.

$57 \quad$ Id. at 104. 
The organization's seizure by the jurisdiction of a member state will vitiate such confidence in a way that it threatens the possibility that the organization, for fear of the adjudication, would act in preference to the jurisdictional state to the discrimination of other member states. Therefore, privileges and immunities for the organizations are necessary to ensure a feeling of equality among member states. In addition, privileges and immunities form a part of prestige and authorities that an international organization enjoys vis-à-vis other similar organizations. ${ }^{58}$

Functional necessity can serve as a basis for justifying the granting of privileges and immunities to international organizations. At the same time, it can also serve as a criterion that defines the scope of immunities that an organization may be entitled to. ${ }^{59}$ Admittedly, mere the concept of functional necessity will not remove all ambiguities in demarcating the scope of immunities for international organizations, but functional necessity can be a useful guideline in determining what immunities should be granted. ${ }^{60}$ As stated above, function implies an international organization's purpose and objectives. Therefore, an examination of an organization's purposes and objectives is indispensable in delimiting the scope of immunities the organization can enjoy. For the great majority of the existing international organizations, their purposes and missions are usually set forth in their constituent instruments. Thus, "the functional necessity criterion can only operate in close cooperation with the instrument embodying the organization's 'necessary functions.' "61 Another relevant factor is the nature of an international organization's function. Arguably, the more activities of political nature that an organization may encounter in performing its functions, the more privileges and immunities the organization should be entitled to. Some scholars suggest that the United Nations, by its nature, is a political international organization and therefore should sit "at the top of the pyramid of privileges and immunities to be accorded to international organization." ${ }^{2}$ In other words, the privileges and immunities enjoyed by the United Nations should represent the maximum standard in determining whether a similar immunity should be granted to a particular international organization. In contrast to the United Nations, as the political nature in an organization's functions reduces to an extent that the organization must enter the marketplace and participate in purely commercial

$\begin{array}{ll}58 & I d . \text { at } 107-108 . \\ 59 & I d . \text { at } 113 . \\ 60 & I d . \\ 61 & I d . \\ 62 & I d . \text { at } 114 .\end{array}$


competition, the organization should possess the minimum degree of immunities, if any immunity at all must be granted. ${ }^{63}$

According to the functional necessity concept, the MDBs, as international organizations, should be entitled to only those privileges and immunities that it strictly needs for the exercise of its functions in the fulfillment of its purposes. ${ }^{64}$ In any sense, the MDBs shall not enjoy more privileges and immunities than the United Nations does.

\section{Application of Immunity Theory on Multilateral Development Banks}

After having set out the principles and rationale regarding granting immunities to international organizations, this Section will examine immunities for MDBs in particular in public international law, domestic legislations, and judicial practices.

\subsection{Immunity for MDBs under International Law}

The primary source of MDBs' immunities is international treaties, which include the constituent instruments of the MDBs. In almost all existing MDBs' Articles of Agreement (AOA) or establishing agreement, there is a specific provision stipulating the immunities that the MDB enjoys. The Articles of Agreement of the IBRD provide:

Actions may be brought against the Bank only in a court of competent jurisdiction in the territories of a member in which the Bank has an office, has appointed an agent for the purpose of accepting service or notice of process, or has issued or guaranteed securities. No actions shall, however, be brought by members or persons acting for or deriving claims from members. The property and assets of the Bank shall, wheresoever located and by whomsoever held, be immune from all forms of seizure, attachment or execution before the delivery of final judgment against the Bank. ${ }^{65}$

This provision seems to suggest that the immunity for the IBRD from national jurisdictions is not absolute, so long as the action is brought in a

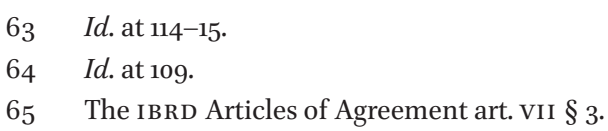


jurisdiction in the territories of an IBRD member state. But this provision does not specify on the types of claims that can be brought against the IBRD. On this issue, the immunity provisions in the establishing agreements of both the ADB and the AIIB, which are almost identical, are more specific: 66

The Bank shall enjoy immunity from every form of legal process, except in cases arising out of or in connection with the exercise of its powers to raise funds, through borrowings or other means, to guarantee obligations, or to buy and sell or underwrite the sale of securities, in which cases actions may be brought against the Bank in a court of competent jurisdiction in the territory of a country in which the Bank has an office, or has appointed an agent for the purpose of accepting service or notice of process, or has issued or guaranteed securities. ${ }^{67}$

EBDB's Headquarters Agreement expands the scope of exceptions to immunities. In addition to the above exception of commercial transactions, ${ }^{68}$ an action arising out personal injuries, or enforcement of an arbitration award made against the bank, also falls within the permissible types of actions that can be brought against the bank and therefore is included in the jurisdiction of local courts. ${ }^{69}$ Such expanded exceptions to immunities are found in other international treaties, such as the Headquarters Agreement between the Chinese government and the АIIв. ${ }^{70}$

The national courts, however, can use techniques to avoid application of the MDBs' constituent instruments that grant immunities to the MDBs. ${ }^{71}$ For

66 The following provision is quoted from the АIIB version. The ADв version is available at Agreement Establishing the Asian Development Bank, Art. 50 § 1.

67 AIIB AOA Art. 46.1.

68 EBRD Headquarters Agreement defines the commercial-transaction waiver as "civil action arising out of the exercise of its powers to borrow money, to guarantee obligations and to buy or sell or underwrite the sale of any securities". E BRD Headquarters Agreement, Art. 4.1.

69 EBRD defines other situations for waiver, i.e., express waiver by the Bank, damage arising from a road traffic accident caused by Bank staff, death or personal injury caused by Bank staff in the UK, enforcement of an arbitration award made against the Bank, and a counter-claim directly connected with court proceedings initiated by the Bank. EBRD Headquarters Agreement, Art. 4.1.

70 AIIB Headquarters Agreement, Art. 4.1, available at http://euweb.aiib.org/html/aboutus/ Institutional_Documents/HQA/?show=4 (visited January 15, 2017).

71 August Reinisch, International Organizations Before national Courts $178(2000)$. 
example, even if the MDB's constituent instrument has been ratified by the legislature of the state where the court sits, the constituent instrument, as an international treaty, is not necessarily self-executing if that state adopts a dualist legal system. In a dualist legal system, an international treaty is not directly applicable in the state's judicial proceedings until the treaty has been formally incorporated into national legislations. ${ }^{72}$

Another source of immunities for MDBs is customary international law, which is legally binding and must be abided by all states. Customary international law is largely a gap-filling source for immunities when there is no applicable international treaty or domestic legislation. ${ }^{73}$ Customary international law may be relevant in cases involving $\mathrm{MDBS}$, when the action against an $\mathrm{MDB}$ is brought in a court of a state that is not a member of the MDB and that does not have regulations specific on granting immunities to international organizations. As a general rule of public international law, widespread state practices and opinion juris must exist in order to find customary international law. It has been suggested that a customary international law exists that international organizations enjoy necessary privileges and immunities independently of international treaties. ${ }^{74}$ The most evident example is the United Nations. "The rules governing privileges and immunities [of the UN] were stated to have acquired the status of norms of international law, there being no difficulty with regard to the content of the law, which form a juridical standpoint was considered clear and well-developed."75 With respect to other international organizations, the evidence most frequently cited by scholars to prove the status of customary international is that privileges and immunity clauses exist comprehensively in international organizations' constituent instruments. This is an implied expression of the willingness and feeling of obligation by states that immunities should be granted to international organizations. ${ }^{76}$ Noticeably, however, the customary international law related to international organizations' immunities does not speak on the scope of the immunities.

\footnotetext{
72 Id. 178-79.

73 Peter H.F. Bekker, The Legal Position of Intergovernmental Organizations: A Functional Necessity Analysis of Their Legal Status ANd Immunities 144 (1994) (citing Szasz, Immunities 155).

74 Id. at 149.

75 Id. at 145 .

$76 \quad$ Id. at 149 .
} 


\subsection{Immunity for MDBs in National Legislation}

Another principal source for international organizations' immunities lies in domestic legislations. Here, we will focus on U.s. law and the interpretations of the law by U.S. court. The International Organizations Immunity Act of 1945 (IOIA) stipulates the immunity of international organizations in U.s. jurisdiction. The statute provides: "International organizations, their property and their assets, wherever located, and by whomever held, shall enjoy the same immunity from suit and every form of judicial process as is enjoyed by foreign governments." ${ }^{77}$ According to the IOIA, international organizations enjoy privileges and immunities in U.S. courts to the extent equivalent to that accorded to foreign sovereignties. The IOIA was promulgated over seventy years ago, in an era when the prevalent view of state sovereignty and immunities still preferred the absolute doctrine but also had seen a decline of the sanctity of states and a rise of the theory of restrictive immunity. ${ }^{78}$ In the light of this background, what the U.s. Congress had in mind with respect to the level of immunities for states when it selected the words "the same immunity ... as is enjoyed by foreign government" becomes a critical issue in understanding the IOIA. Furthermore, the question of whether the scope of the immunities for international organizations changes with the evolution of state immunity after the Foreign Sovereign Immunity Act (FSIA) was adopted in 1970 os must be answered before the level of immunities for international organizations in U.S. law can be determined. These two vital issues were examined by the United States Court of Appeals for the District of Columbia Circuit (D.C. Circuit) in Atkinson v. Inter-American Development Bank. ${ }^{79}$

The D.C. Circuit did not address the first issue in details. The court merely asserted that "when Congress enacted the IOIA in 1945, foreign sovereigns enjoyed ... virtually absolute immunity"; 80 it did not provide further review of the law for sovereign immunity during that period. The court then rejected the appellant's contention that the IorA incorporated the subsequent change to sovereign immunity in the FSIA; therefore, the IOIA does not follow suit of the FSIA that accepted the restrictive theory of immunity. ${ }^{81}$ The court acknowledged that the text of the IOIA does not provide an express guidance on whether the Congress intended to incorporate the subsequent changes to the

7722 U.S.C $\$ 228 \mathrm{a}(\mathrm{b})$.

78 Steven Herz, Ineternational Organizations in U.S. Courts: Reconsidering the Anachronism of Absolute Immunity, 31 Suffol K TransNAT'L L. REV. 471, 478-79 (2008).

79156 F.3d 1335 (D.C. Circuit, 1998).

8 o Id. at 1340 .

$81 \quad$ Id. at 1341. 
law governing the state sovereign immunity. ${ }^{82}$ Despite the ambiguity, however, the court declined to consider the interpretation canon, which requires that a statute which refers to a subject adopts all the amendments and modifications of the law subsequent to the time the reference statute was enacted. ${ }^{83}$ The denial of this interpretation canon, according to the D.c. Circuit, was based on the fact that the IOIA sets forth a separate mechanism for monitoring and amending the immunities of international organizations: "the President retains authority to modify, condition, limit, and even revoke the otherwise absolute immunity of a designated organization." 84

This construction of the IOIA by the D.C. Circuit has invited strong criticisms. First, the D.c. Circuit wrongfully denied consideration of the interpretation cannon in construing the meaning of the IOIA. The cannon that a statute shall incorporate all subsequent amendments of the law it refers to has been a well-established principle when the Congress enacted the IOIA. ${ }^{85}$ Therefore, the interpretation cannon should be understood as having been taken into account by the Congress in drafting the IOIA, unless there was explicit evidence that the Congress did not intend the canon to apply. ${ }^{86}$ The canon is not merely a secondary and negligible tool in the court's construction of the IOIA; rather, the IOIA should be interpreted in accordance with the canon. ${ }^{87}$ Second, the foreign sovereign immunity that the IOIA referred to was not absolute at the enactment of the IOIA. In a line of cases decided in that era, the judicial branch gave deference to the executive's determination on the level of immunity enjoyed by foreign sovereigns. ${ }^{88}$ Thus, the privileges and immunity entitled to foreign sovereigns were granted by the executive branch on a case-by-case basis. If strictly construing the language "the same ... as is enjoyed by foreign government," the D.c. Circuit should ask the administration in charge of foreign affairs for advice on the status of foreign sovereigns at the current time. ${ }^{89}$

\footnotetext{
$82 \quad I d$.

83 Id.

84 Id. Although the court did not point to the specific text it referred to that delegates the President the power to monitor and amend the immunities of international organizations, the court clearly meant 22 U.s.c. $§ 288$., which stipulates that when an international organization abuses its privileges, the immunity may be revoked by executive order.

85 Steven Herz, International Organizations in U.S. Courts: Reconsidering the Anachronism of Absolute Immunity, at 498 .

86 Id.

87 Id. at $498-99$.

88 Id. at $503-10$.

89 Id. at $510-11$.
} 
If the Atkinson decision was not a proper construction of the IOIA, the IOIA, by its reference to the immunity enjoyed by foreign governments, should be understood as having incorporated the subsequent change to the law of sovereign immunity represented in the FSIA. Thus, the exceptions to immunity, such as commercial activities and tortious act, will apply in a case where an international organization is involved. Accordingly, when actions against MDBS are brought in U.s. courts, the MDBs should be subject to the exceptions to immunity in the same manner as foreign states.

\subsection{Judicial Interpretations of Immunity for MDBs}

In Mendaro v. World Bank, the D.c. Circuit stated that pursuant to the IoIA, international organizations are generally entitled to immunity from judicial proceedings, but the immunity conferred is subject to two limitations. First, the organization may expressly waive its immunity; second the President may specifically limit the organization's immunities. ${ }^{90}$ In interpreting the immunity provision in the World Bank's Articles of Agreement, the D.c. Circuit held that "the immunity of an international organization may be waived only by an express waiver on the part of the organization,"91 and a general statement permitting suits to be brought against the bank should not be deemed as an express waiver of immunity within the meaning of the limitations on immunity conferred to the bank.$^{92}$ According to the court's interpretation, the immunity clause in the IBRD's Articles of Agreement, which provides that "[a]ctions may be brought against the Bank only in a court of competent jurisdiction in the territories of a member," is in fact granting the bank absolute immunity, so long as the bank does not waive the immunity explicitly.

But the absence of the World Bank's express waiver of immunity was not the primary basis on which the court restrained its jurisdiction in Mendaro. The court ruled for the bank because the action against the bank arose out of an employment relationship. According to the court, "one of the most important protections granted to international organizations is immunity from suits by employees of the organization in actions arising out of the employment relationship," and the purpose of such immunity "is rooted in the need to protect international organizations from unilateral control by a member nation over the activities of the international organization within its territory."93 Based on

\footnotetext{
$90 \quad$ Mendaro v. World Bank, 717 F.2d 610, 613 (D.c. Circuit, 1983).

91 Id. at 617 (quoting the Restatement (Second) of the Foreign Relations Law of the United States $\S 84(1965))$.

$92 \quad I d$.

93 Id. at 615 .
} 
this reasoning, the court's granting of absolute immunity to the bank should be narrowly read to be limited to the situations where the underlying legal relationship of the action is an internal employment relationship. ${ }^{94}$ This reading is confirmed by the court's statement that with respect to the bank's internal operations, a waiver of immunity to suits would contravene the bank's Articles of Agreement. ${ }^{95}$

However narrow the decision in Mendaro can be read, the D.c. Circuit still recognized that international organizations shall enjoy absolute immunity from judicial proceedings, unless the immunity is expressly waived by the bank or by the U.s. President. The United States Court of Appeals for the Third Circuit, however, reached an opposite conclusion in another case Oss Nokalva, Inc. v. European Space Agency in 2010. Although the defendant in that case was not an MDв as in Mendaro, the decision is still enlightening because it provides a different interpretation of the IOIA, which certainly governs the immunity enjoyed by MDBs, from the interpretation offered by the D.C. Circuit in Atkinson and Mendaro. The Third Circuit in European Space Agency reexamined the D.C. Circuit's holding in Atkinson that the IOIA, while granting international organizations the immunity as enjoyed by foreign sovereigns, does not mean to incorporate the subsequent change to the law of sovereign immunity in the FSIA. ${ }^{96}$

First, the Third Circuit disagreed with the D.c. Circuit in Atkinson, which declined to consider the interpretation canon in construing the meaning of the Iогі. ${ }^{97}$ The court also noticed the fact that nearly half of the international organizations recognized by the United States came into existence after the FSIA was enacted in 1976. ${ }^{98}$ The court then reasoned that "it is unreasonable to assume that those international organizations that were established under the IOIA after foreign sovereign immunity had been altered by the FSIA would still be subject to that level of immunity enjoyed by foreign governments and

94 For example, АІІв Headquarters Agreement Article 17.3 provides:

"The terms and conditions of the Officers and Employees of the Bank and experts and consultants performing missions or services for the Bank, and all matters relating to employment relations between such persons and the Bank, shall be governed exclusively by the Bank's own employment rules, policies and procedures adopted by or under the authority of the Bank's Board of Directors, and shall not be subject to the labor laws of the People's Republic of China."

$95 \quad I d$. at 618.

96 oss Nokalva, Inc. v. European Space Agency, 617 F.3d 756, 762 (3rd Cir. 2010).

97 Id. at 763 .

$98 \quad$ Id. at 764 . 
international organizations in $1945 .{ }^{\prime 99}$ Moreover, according to the court, if the Congress wanted the international organizations' immunity to remain as it existed in 1945, it could have used explicit languages for this effect. ${ }^{100}$ From a policy point of view, the court concerned that if giving a group of states acting through an international organization broader immunity than that accorded to a member state when it acts on its own, it will create a loophole that a state may exploit to evade legal obligations by acting through international organization. ${ }^{101}$ More importantly, the Third Circuit distinguished European Space Agency from Atkinson and Mendaro by pointing out that the latter two cases addressed claims based on internal employment relationship, while the former dealt with tort claims arising out of external commercial transactions of the defendant organization. ${ }^{102}$

\section{$5 \quad$ Counterbalance of Multilateral Development Bank Immunity}

Being absolute or restrictive, immunity does not mean impunity. As the European Court of Human Rights (ECHR) held in the Waite and Kennedy Case, 'a material factor in determining whether granting ... immunity from ... jurisdiction is permissible is whether the applicants had available to them reasonable alternative means to protect effectively their rights under the Convention'. ${ }^{103}$ The International Court of Justice (ICJ) has endorsed similar viewpoints more than once. ${ }^{104}$

Thus, the private parties' right to a fair trial becomes another justification for an MDB's immunity from legal process, besides the doctrine of functional necessity. And the M DB's immunity should not compromise this right. It is thus important for the MDB to establish adequate dispute settlement systems within itself as necessary complements and counterbalance of its immunity from jurisdiction. The Administrative Tribunal and the accountability mechanism mark the MDB's splendid endeavor in this regard.

\footnotetext{
$99 \quad I d$.

100 Id.

101 Id.

$102 I d$. at 765 .

103 ECHR, Case of Waite and Kennedy v. Germany (Application no. 26083/94) 18 February 1999, para. 68.

104 The ICJ clears its attitude towards immunity in both the Cumaraswamy case and its 1954 advisory opinion in the Effect of Awards case. Rutsel Silvestre J. Martha, 'International Financial Institutions and Claims of Private Parties', in Hassane Cisse, etc. (ed.), The World Bank Legal Review, Vol. 3 (2012) at 118.
} 


\subsection{Administrative Tribunal}

An MDв enjoys immunity of jurisdiction from the courts of its member countries for an employment dispute arising between the bank and its staff members. ${ }^{105}$ For this reason, each MD B establishes an Administrative Tribunal as an independent judicial forum for the resolution of employment disputes. The Tribunal is autonomous from Bank management, and its decisions are binding and final.

The Tribunal is made up of several judges of whom three form a quorum to hear a case typically. ${ }^{106}$ The Tribunal's members are appointed by the Board from a list of candidates drawn up by the Bank president. ${ }^{107}$ The Tribunal is served by a small secretariat or registry, responsible for receiving, maintaining, and transmitting the pleadings in the case. ${ }^{108}$

The Tribunal's members must possess the qualifications required for appointment to high judicial office or be jurisconsults of recognized competence. ${ }^{109}$ They are appointed for fixed terms and are completely independent in the exercise of their duties. ${ }^{110}$ They may not have any prior or present employment relationship with the Bank. ${ }^{111}$ Nor are they eligible for staff employment with the Bank following the end of their service with the Tribunal. ${ }^{112}$

\footnotetext{
105 "Staff member" means any current or former member of Bank staff. World Bank Administrative Tribunal Statute (as amended June 18, 2009), Art. II.3, https://webapps .worldbank.org/sites/wbat/Pages/Statute.aspx (visited December 10, 2016).

106 The World Bank is exceptional in the sense that five members of its Tribunal form a standard quorum to hear a case, while a Tribunal of three members is also permissible. World Bank Administrative Tribunal Statute (as amended June 18, 2009), Art. v, https://webapps .worldbank.org/sites/wbat/Pages/Statute.aspx (visited December 10, 2016).

107 World Bank Administrative Tribunal Statute (as amended June 18, 2009), Art. IV.2, https:// webapps.worldbank.org/sites/wbat/Pages/Statute.aspx (visited December 10, 2016).

108 Statute of the Administrative Tribunal of the AfDB, Art. viII. available at http://www .afdb.org/fileadmin/uploads/afdb/Documents/Administrative-Tribunal/Statute\%20 of\%2othe\%2oAdministrative\%2oTribunal_1312.pdf (visited December 10, 2016).

109 The Tribunal members possess competence in relevant fields such as employment relations, international civil service and international organization administration. World Bank Administrative Tribunal Statute (as amended June 18, 2009), Art. IV.1, https:// webapps.worldbank.org/sites/wbat/Pages/Statute.aspx (visited December 10, 2016).

110 Statute of the Administrative Tribunal of the AfDB, Art. VI.4 and Art. viI.1, available at http://www.afdb.org/fileadmin/uploads/afdb/Documents/Administrative-Tribunal/ Statute\%20of\%2othe\%2oAdministrative\%2oTribunal_1312.pdf (visited December 10, 2016).

111 World Bank Administrative Tribunal Statute (as amended June 18, 2009), Art. IV.1, https:// webapps.worldbank.org/sites/wbat/Pages/Statute.aspx (visited December 10, 2016).

112 World Bank Administrative Tribunal Statute (as amended June 18, 2009), Art. IV.1, https:// webapps.worldbank.org/sites/wbat/Pages/Statute.aspx (visited December 10, 2016).
} 
The Tribunal hears complaints made by a staff member alleging non-observance of his contract of employment or terms and conditions of appointment. Matters falling within the jurisdiction of the Tribunal include, for example, decisions regarding the payment of staff benefits, promotion, performance evaluation, separation from the service of the Bank, as well as disciplinary measures taken against a staff member. ${ }^{113}$ Appropriate remedies to the complainant include compensatory remedies, and rescinding or rectifying the disputed administrative decision. ${ }^{114}$

The Tribunal adjudicates a case based on the Bank's internal law comprising the AOA, Bank rules, regulations, policies and procedures. ${ }^{115}$ The AfDB Tribunal may interpret the legal texts by referencing the jurisprudence of peer institutions. The Tribunal applies generally recognized principles of international administrative law concerning the resolution of employment disputes of staff in international organizations. All MD Bs' Tribunals publish their judgments and orders, which are available on their official websites. A growing body of those cases expects to enrich international administrative law.

The Administrative Tribunal is the final step in the recourse mechanism for aggrieved staff members. And this opportunity is only available when a complainant has exhausted all other remedies available within the Bank. ${ }^{116}$ The AfDB, for example, has a few specialized appeals mechanisms to adjudicate specified matters such as job evaluation, sexual harassment or staff pension plans. Some of the mechanisms are permanent while others being ad hoc, created as needed to resolve specific matters. ${ }^{117}$ A similar situation exists in the

113 http://www.afdb.org/en/about-us/organisational-structure/administrative-tribunal/

114 World Bank Administrative Tribunal Statute (as amended June 18, 2009), Art. XII.1, https://webapps.worldbank.org/sites/wbat/Pages/Statute.aspx (visited December 10, 2016). Statute of the Administrative Tribunal of the AfDB, Art.XIII.

115 Statute of the Administrative Tribunal of the AfDB, Art. v, available at http://www.afdb. org/fileadmin/uploads/afdb/Documents/Administrative-Tribunal/Statute\%20of\%20 the\%20Administrative\%2oTribunal_1312.pdf (visited December 10, 2016).

116 There are situations where administrative remedies available may be deemed to have been exhausted; for example, the complainant and the Bank may agree to submit the case directly to the Tribunal. An illustration of such possible situations may be referenced at Statute of the Administrative Tribunal of the IMF (as amended 2009), Art. v, available at http://www.imf.org/external/imfat/statute.htm (visited December 10, 2016).

117 The AfDB's permanent specialized appeals mechanisms include Ombudsman, Staff Appeals Committee, Disciplinary Committee, Pension Appeals Committee, etc. The ad hoc appeals mechanisms include Special Job Classification Appeals Committee, Panel of Enquiry on Harassment, etc. http://www.afdb.org/en/about-us/organisational-structure/ administrative-tribunal/ (visited December 10, 2016). 
World Bank. ${ }^{118}$ The complainant must first resort to one of those mechanisms as applicable before proceeding with the Tribunal.

The competence of some MDBs' Tribunal may be extended to any international organization, subject to agreements made with each such organization by the MDBs. ${ }^{119}$ That is to say, if the international organization does not institute a mechanism to handle employment disputes within itself, or the mechanism is not available due to some reason, that organization may utilize the MDBs' mechanisms for resolving disputes.

\subsection{Accountability Mechanism}

MDBs have a "clear international obligation to avoid causing environmental harm in developing member countries and indeed to incorporate environmental protection and social development objectives into all of their activities."120 Such primary obligation cannot be observed or duly fulfilled in absence of an appropriate secondary obligation that enforces the MDBs to pay for the damages it has caused. Those adversely affected by the MDBs-assisted projects should be entitled to an opportunity to have their complaints heard in a fair trial. But the MD Bs' claim of immunity hinders the grieved parties' recourse to judicial remedies in local jurisdictions.

The accountability mechanism is essentially MDBs' legal efforts to address complaints made by people adversely affected by an MDB-funded project. ${ }^{121}$ Such complaints arise from concerns with environmental and social

118 See the World Bank's Internal Justice Services, which are available to staff in addressing their workplace concerns, http://web.worldbank.org/WBSITE/EXTERNAL/ EXTABOUTUS/ORGANIZATION/ORGUNITS/EXTCRS/o,,menuPK:64165918 pagePK:641 65931 piPK:64166031 theSitePK:465567,0o.html (visited December 26, 2016).

119 World Bank Administrative Tribunal Statute (as amended June 18, 2009), Art. Xv, https:// webapps.worldbank.org/sites/wbat/Pages/Statute.aspx (visited February 25, 2017). Other international organizations have similar mechanisms, for example, Statute of the Administrative Tribunal of the IMF (as amended 2009), Art. XXI.

120 Gunther Handl, The Legal Mandate of Multilateral Development Banks As Agents for Change Toward Sustainable Development, 92 AM. J. INT'L L. 642, 664 (1998).

121 In this article, the accountability mechanism is defined with a narrow approach. A broader definition may include, in addition to the Inspection Panel as defined in this article, in the case of the World Bank, such other mechanisms as the Administrative Tribunal, the Internal Auditing Department (IAD), the Independent Evaluations Group (IEG), and the Integrity Vice Presidency (INT). Evarist Baimu and Aristeidis Panou, 'Responsibility of International Organizations and the World Bank Inspection Panel', in Hassane Cisse, Daniel D. Bradlow, Benedict Kingsbury (ed.), The World Bank Legal Review, Vol. 3 (2012) at $151^{-3}$. 
implications, including involuntary resettlement and human rights violations. The mechanism investigates whether Bank staff has fulfilled the obligation to comply with Bank rules relating to project design and implementation. ${ }^{122}$

The World Bank built the first accountability system among its peer institutions in $1993 .{ }^{123}$ Pursuant to the Resolution Establishing the Inspection Panel ("the Resolution"), ${ }^{124}$ the Inspection Panel is independent from Bank management. ${ }^{125}$ The Panel reports exclusively to the Board, ${ }^{126}$ rather than to the President. The Panel has three permanent members, ${ }^{127}$ each of whom serves for one non-renewable term of five years. ${ }^{128}$ Panel members cannot have served the Bank in any capacity for the two years preceding their selection, ${ }^{129}$ and can never work for the Bank after the five-year term ends. ${ }^{130}$ The Panel has a separate Secretariat. ${ }^{131}$

Panel independence from management has strong evidence in practice as well. For example, some Panel members had extensive experience with environmental NGOs' work, preparing them well for the Panel work; ${ }^{132}$ the

122 Bank rules refer to Bank operational policies and procedures "with respect to the design, appraisal and/or implementation of projects". World Bank, The First Review of the Resolution Establishing the Inspection Panel in 1996 ("the 1996 Clarifications"), Section entitled "Eligibility and Access".

123 As for a detailed, official description of the establishment of the Inspection Panel, see World Bank, "The Inspection Panel at 15 Years" (2009), at 3-4, available at http:// documents.worldbank.org/curated/en/997441468157510017/The-inspection-panel-atfifteen-years (visited November 22, 2016).

124 The Board issued the Resolution in 1993, and subsequently issued the First Review of the Resolution Establishing the Inspection Panel in 1996 ("the 1996 Clarifications"), and the Second Review of the Resolution Establishing the Inspection Panel in 1999 ("the 1999 Clarifications"). The texts of these legal documents are available at World Bank, "The Inspection Panel at 15 Years" (2009), at 202-13, http://documents.worldbank.org/curated/ en/997441468157510017/The-inspection-panel-at-fifteen-years (visited November 22, 2016).

125 Andres Rigo Sureda, 'Process Integrity and Institutional Independence in International Organizations: the Inspection Panel and the Sanctions Committee of the World Bank', in Laurence Boisson de Chazournes et al. (eds), International Organizations and International Dispute Settlement (Transnational Publishers, 2002), at 172.

126 The Inspection Panel at the World Bank: Operating Procedures (April 2014), at 7.

127 The Resolution, para. 2.

128 The Resolution, para. 3 .

129 The Resolution, para. 5 .

130 The Resolution, para. 10.

131 The Inspection Panel at the World Bank: Operating Procedures (April 2014), at 7.

132 Ibrahim F.I. Shihata, The World Bank Inspection Panel: In Practice (New York: Oxford University Press, 2000), second edition, at 206-7. 
Panel often disagrees with Bank management regarding the eligibility and evaluation of requests; ${ }^{133}$ and the Panel has even been outspoken in criticizing management. ${ }^{134}$

Over time, the Inspection Panel system has presented some important advantages and achievements. First, where letters written from local communities were frequently ignored, Panel claims immediately triggers attention from the highest levels of the Bank. As a result, immediate positive results occur on the ground. ${ }^{135}$ Second, the Inspection Panel enriches corporate governance of the Bank, counterbalancing the power of management by placing its operational team under broad-based, strict scrutiny. Third, the system improves Bank rule-making process and quality, through the dynamic work of interpreting and applying Bank rules and procedures. Fourth, a perhaps unintended benefit is that the Bank is offered the opportunity to defend itself before a credible forum. ${ }^{136}$ This is particularly important for the Bank given the mounting accusations of the public who often lack accurate information but feel free to blame project failures on the Bank. ${ }^{137}$

As of July 22, 2017, the Inspection Panel has processed 119 cases. ${ }^{138}$ Other MDBs created compliance review mechanisms patterned loosely after the Inspection Panel. ${ }^{139}$ These M D Bs generally publish their judgments and orders,

133 Ibrahim F.I. Shihata, The World Bank Inspection Panel: In Practice (New York: Oxford University Press, 2000), second edition, at 206-7.

134 Andres Rigo Sureda, 'Process Integrity and Institutional Independence in International Organizations: the Inspection Panel and the Sanctions Committee of the World Bank', in Laurence Boisson de Chazournes et al. (eds), International Organizations and International Dispute Settlement (Transnational Publishers, 2002), at 173.

135 For example, the first Panel claim led directly to the cancellation of the Arun Dam by President Wolfensohn. Another claim led to the inclusion of the Char people in the resettlement program of Bank-financed Jamuna Bridge. David Hunter, 'Using the World Bank Inspection Panel to Defend the Interests of Project-affected People', 4 Chi. J. Int'l L. 201 2003, at 210 .

136 Ibrahim F.I. Shihata, The World Bank Inspection Panel: In Practice (New York: Oxford University Press, 2000), second edition, at 240.

137 For example, ICIJ and HuffPost, 'How The World Bank Broke Its Promise To Protect The Poor', April 15, 2015, http://projects.huffingtonpost.com/worldbank-evicted-abandoned (visited December 20, 2016).

138 See a complete case list at http://ewebapps.worldbank.org/apps/ip/Pages/Panel_Cases .aspx (visited July 22, 2017).

139 These other compliance review mechanisms include the ID B's Independent Investigation Mechanism established in 1994, superseded by the enhanced Independent Consultation and Investigation Mechanism in 2010; ADB's inspection function first established in 1995, replaced by the Accountability Mechanism (introducing the permanent Compliance 
showing how MDBs approach each case on its merits, and explain what offenders did wrong. The cases are thus valuable sources of precedent, contributing to a seemingly distant droit commum across MDBs. ${ }^{140}$ More important, the cases have been enriching other areas of international law, including international human rights law, international environmental law, and international administrative law. ${ }^{141}$

The AII B prioritizes the establishment of a credible accountability culture and mechanism. AІгв Articles of Agreement explicitly authorizes the Board of Directors to establish an oversight mechanism for supervising Bank management and its operations "on a regular basis" and "in line with principles of transparency, openness, independence and accountability."142 АІІв Environmental and Social Framework in particular provides for an oversight mechanism to respond to complaints from project-affected communities with the goal of enhancing social and environmental outcomes on the ground. ${ }^{143}$ The mechanism is under construction at the time of writing, ${ }^{144}$ and is very much looked forward to. ${ }^{145}$

Review Panel) in 2003 and updated in 2012; IFC/MIGA's Compliance Advisor Ombudsman (CAO) in 1999; E B RD's Independent Recourse Mechanism in 2003; and AfDB's Independent Review Mechanism in 2004, updated twice in 2010 and 2015.

140 The notion "droit commum" is defined as a process through which various organizations develop and implement similar standards, rules, or procedures. A droit commun allows for the emergence of a distinct legal corpus of the harmonized standards, rules, and procedures that the institutions have in common. Laurence Boisson de Chazournes, 'Partnership, Emulation, and Coordination: Toward the Emergency of a Droit Commum in the Field of Development Finance', in Hassane Cisse, Daniel D. Bradlow, Benedict Kingsbury (ed.), The World Bank Legal Review, Vol. 3 (2012) at 174.

141 Daniel D. Bradlow, 'International Organizations and Private Complaints: The Case of the World Bank Inspection Panel', 34 Va. J. Int'l L. 553 1993-1994, at 6o8-10.

142 AIIв AOA Article 26 (iv).

143 АІІв Environmental and Social Framework (February 2016) paragraph 64 offers a general provision on the oversight mechanism.

64. Bank Oversight Mechanism. People who believe they have been or are likely to be adversely affected by a failure of the Bank to implement the ESP may also submit complaints to the Bank's oversight mechanism in accordance with the policies and procedures to be established by the Bank for such mechanism.

144 АІІB, 'Call for Public Consultation for the Proposed Asian Infrastructure Investment Bank (AIIB) Complaints Handling Mechanism' 27 April 2017, available at https://www.aiib.org/ en/policies-strategies/_download/consultation/consultation_aiib.pdf (visited June 24, 2017).

145 Four principle-based proposals for constructing the AIIB's accountability mechanism are available at GU Bin, MDBs' Accountability Mechanism: A Perspective of AIIB, Journal of World Trade, Vol. 51, Issue 3, June 2017. 
The MDBs, alongside other international financial institutions with comparable accountability mechanisms, have established a Network of Independent Accountability Mechanisms. ${ }^{146}$ Through the Network, member institutions exchange ideas and practices, improving their own accountabilities as key components of corporate governance. ${ }^{147}$

6 Conclusion

The MDBs should be entitled to immunity in national courts, but the immunity cannot be absolute that exempts the MDBs from all court proceedings. The rationale behind international organizations' immunity-functional necessity —allows the MDBs to be entitled to immunity only to the extent that is strictly necessary for the MDBs to properly perform their functions and fulfill their purposes.

In practice the MDBs seem to have accepted the theory of restrictive immunity. While the scope of immunities they accept might vary, the following three exceptions to immunity are almost uniformly recognized. The first exception is the MDBs' explicit waiver, which should not be sufficed by a general statement by the banks permitting suits to be brought against them. The second exception refers to the MDBs' commercial transactions with the outside world. The third exception involves a civil action arising from a road accident contributable to the MDB and incurred in the country where that MDB is headquartered.

It is acknowledged that waivers of immunity are not necessarily detrimental to the MDBs' interests. They may rather bring corresponding benefits to help further the MDBs' goal. ${ }^{148}$ Specific to commercial transactions with the MDBs,

146 Membership of the Network of Independent Accountability Mechanisms includes AfDB, ADB, EBRD, European Investment Bank (ЕIB), IDB, Japan Bank for International Cooperation (JBIC), Nippon Export and Investment Insurance (NEXI), Overseas Private Investment Corporation (OPIC), United Nations Development Program (UNDP), World Bank Group-IFC and MIGA (Compliance Advisor Ombudsman, CAO). http://ewebapps. worldbank.org/apps/ip/Pages/Related\%20Organizations.aspx (visited November 22, 2016).

147 The Inspection Panel at the World Bank: Operating Procedures (April 2014), at 21, footnote 11 .

148 In Mendaro, the court held that "it is evident that the World Bank's members could only have intended to waive the Bank's immunity from suits by its debtors, creditors, bondholders, and those other potential plaintiffs to whom the Bank would have to subject itself to suit in order to achieve its chartered objectives." Mendaro v. World Bank, 717 F.2d 610 (D.C.Cir.1983), at 615 . 
parties may hesitate to do business with them if the MDBs are insulated from judicial process. Thus, waiver of immunity for claims arising out of commercial transactions might help to attract prospective parties by reinforcing their expectations of fair play. The young AIIB concurs that any of its immunities is subject to waiver if the waiver is "in the best interests of the Bank". ${ }^{149}$

Some critics argue that MDBs enjoy excessive advantages over their competitors, and that their privileges and immunities put commercial banks in a disadvantaged position in market competition. ${ }^{150}$ This argument is not true. Commercial lenders normally feel uncomfortable to lend long-term development loans alone, since such loans and relevant projects are typically more complicated, much less ready to be liquidated, and thus more risky, than commercial ones. A feasible way for them to participate in development financing is thus to offer blended loans alongside the MDBs, ${ }^{151}$ thereby taking a free ride on the MDBs' privileged position. ${ }^{152}$

The MDB's immunity from legal process must not compromise the MDBaffected private parties' right to a fair trial. Neither an absolute nor a restrictive theory endorses that immunity means impunity. An MD в should establish an adequate dispute settlement system within itself as counterbalance of immunity from domestic legal process. It is noted that the right to a fair trial becomes another justification for an MDB's immunity from legal process, besides the doctrine of functional necessity.

The MDBs have made splendid endeavors to build fair and effective dispute settlement systems from within, among which the accountability mechanism and the Administrative Tribunal are exemplary. It is observed that both these systems within the MDBs have generally been evolving in the optimal direction of independence and impartiality.

149 AIIB AOA Art. 52. АIIB Headquarters Agreement, Art. 18.

150 August Reinisch, International Organizations Before National Courts 262-63 (2000).

151 For example, the AIIB, the International Financial Corporation (IFC) and certain commercial lenders co-finance a greenfield gas-fired power plant in Myanmar, whereby the commercial lenders expect to share the privileges and immunities of the АІІв and the IFC. http://euweb.aiib.org/html/2016/PROJECTS_list_0922/156.html (visited January 15, 2017).

152 For example, commercial banks enjoy preferred creditor status (PCS) thanks to the MDBS in blended financing. See a detailed description of favorable treatments to commercial lenders in blended financing at http://www.ifc.org/wps/wcm/connect/Topics_Ext_ Content/IFC_External_Corporate_Site/IFC+Syndications/Overview_Benefits_Structure/ Syndications/B+Loan+Structure+And+Benefits/ (visited January 15, 2017). 
